\title{
HISTOCHEMICAL ASSESSMENT OF MORINGA - OLEIFERA OIL AND WALNUT OIL ON CADMIUM INDUCED LATERAL GENICULATE BODY DAMAGE IN DEVELOPING MALE WISTAR RATS (Rattus novergiccus)
}

\author{
OMOTOSO OD ${ }^{1,3}$, ADELAKUN SA ${ }^{2 *}$, AKWU BP ${ }^{3}$, OGBONNA E ${ }^{4}$, IDOMEH IJ ${ }^{1}$ \\ ${ }^{1}$ Department of Anatomy, Faculty of Basic Medical Sciences, Bingham University, Karu, Nigeria. \\ 2Department of Human Anatomy, School of Health and Health Technology, Federal University of \\ Technology, Akure, Nigeria. \\ ${ }^{3}$ Department of Anatomy, Faculty of Basic Medical Sciences, Kogi State University, Anyigba, Nigeria. \\ ${ }^{4}$ Department of Pharmacology and Therapeutics, Faculty of Basic Clinical Sciences, Kogi State \\ University, Anyigba, Nigeria.
}

*Correspondence to Adelakun S.A, Department of Human Anatomy, School of Health and Health Technology, Federal University of Technology, Akure, Nigeria. Email: saadelakun@futa.edu.ng. TEL: $+2348133354835$

\section{ABSTRACT}

The brain is vulnerable to oxidative damage due to its high oxygen consumption. This Study investigate the effects of cadmium on the lateral geniculate body of developing male wistar rats and ameliorative potential of Moringa oleifera seed oil and walnut oil extracts. Seven groups of five animals each were used in this experiment. Group A received $3 \mathrm{ml}$ of $0.9 \%$ normal saline; group B received $2.5 \mathrm{mg} / \mathrm{kg}$ bw of $3 \mathrm{CdSO}_{4} .8 \mathrm{H}_{2} \mathrm{O}$, group $\mathrm{C}$ received $5 \mathrm{mg} / \mathrm{kg}$ bw vitamin $\mathrm{C} \& 6 \mathrm{mg} / \mathrm{kg}$ bw vitamin $E$, group $D$ received $5 \mathrm{mg} / \mathrm{kg}$ bw vitamin $C \& 6 \mathrm{mg} / \mathrm{kg}$ bw vitamin $E+2.5 \mathrm{mg} / \mathrm{kg}$ bw Cd, group $\mathrm{E}$ received $2.5 \mathrm{mg} / \mathrm{kg}$ bw $\mathrm{Cd}+4 \mathrm{mg} / \mathrm{kg}$ bw Moringa oleifera oil, group F received $2.5 \mathrm{mg} / \mathrm{kg}$ bw $\mathrm{Cd}+4 \mathrm{mg} / \mathrm{kg}$ bw walnut oil, while group $\mathrm{G}$ received $2.5 \mathrm{mg} / \mathrm{kg}$ bw $\mathrm{Cd}+2 \mathrm{mg} / \mathrm{kg}$ bw walnut + $2 \mathrm{mg} / \mathrm{kg}$ bw Moringa oleifera oil concomitantly for 3weeks. Parameter tested includes LDH, G6PD in brain tissues, SOD and GPx enzymes in brain homogenates and serum and cresyl fast violet stain in the brain tissues. Cd administration significantly increased SOD, GPx, LDH and decreased G6PD level in brain tissue and decreased their activity in serum when compared with Group A control rats. There was marked reduction and lost in the distribution of nissl substances of the studied tissues of $\mathrm{Cd}$ administered animals. However, administration of vitamin C \& $\mathrm{E}$, walnut and Moringa oleifera oil restored damaged tissues. Walnut and Moringa oleifera seed oil therefore attenuated the oxidative damage and morphological changes induced by cadmium in the lateral geniculate body of the brain of the young male wistar rats.

Key Words: Lateral geniculate body, Antioxidant, Histochemical, Cadmium, Oxidative Damage

\section{INTRODUCTION}

Cadmium is a silver-white, blue-tinged, lustrous metal that melts at $321^{\circ} \mathrm{C}$ and boils at $765^{\circ} \mathrm{C}$ (Bertin and Averbeck 2006). This divalent element has an atomic weight of 112.4 and an atomic number of 48 (The'venod, 2009). It is insoluble in water, although its chloride and sulphate salts are freely soluble (Windholz et al., 1976). The word Cadmium is derived from "Kadmeia" the ancient name for calamine (zinc carbonate) (Nawrot et al., 2008). The element Cadmium was discovered in 1817 as an impurity in Calame (Government of Canada, 1994). It is a rather rare element in nature (Cadmium mineral. greenockite) with small amounts of Cadmium king found in Zinc, Copper and Lead 
ores (Islamoglu et al.,2006, Pietrobelli et al.,2009). Cadmium is generally a by-product of working with these metal ores and, therefore, its presence in the environment is essentially due to industrial waste (Wang and Gao,2009). In addition to being a by-product of Zinc and Lead mining, Cadmium is used in the Chemical industry for manufacture of such products as batteries, pigments, alloys, paints and plastics as well as in electroplating (Kurniawan et al.,2006, Liang et al.,2007). Cadmium once absorbed gets accumulated in major organs of the living system (Deepti et. al., 2011). Thus, the risk of chronic intoxication is the biggest problem, the chronic effects of cadmium depend on dose and on the route by which the metal enters the body and chronic inhalation causes emphysema and obstructive airways disease, before kidney damage is visible (Jahangir et. al., 2005). Yellow tooth discoloration, mild anemia, and disturbances in calcium metabolism, osteomalacia, and renal toxicity also are observed occasionally (Gonick, 2008). Cadmium has been shown to affect virtually every organ and system in the body in both humans and animals (Houshmandfar and Moraghebi, 2011, Sears et al., 2012). Cadmium is also known to be carcinogenic, and has been linked with cancers of the lungs and prostate, pancreas and kidney (Khausakorn et al., 2012). The prostate is a potential target for Cadmium carcinogenesis, although the underlying mechanisms are still unclear (Aimola et al., 2012).

Moringa oleifera L (Moringaceae) known commonly as Ben oil tree or drumstick tree in English language,'Okweoyibo' in Igbo, 'Zogale'or 'Gawara' or 'Habiwal' in Hausaand' Adagbamaloye' or 'Ewe Igbale' in Yoruba grows rapidly in most regions and climatic conditions of Nigeria(Ogbunugafor et al., 2011). Moringa oleifera is a tropical multipurpose tree that naturally grows in India, South Saharan Africa and SouthAmerica (Jahn,1988). Moringa oleifera originates in India, from the valleys of the southern Himalayas and today it can be found along the tropical and subtropical zones (Fuglie, 1999). Moringa oleifera is the most widely spread species of the plant family
Moringaceae (Abaliwano, 2008). In particular, this plant family is rich in compounds containing the simple sugar, rhamnose, and it is rich in a fairly unique group of compounds called glucosinolates and isothiocyanates (Bennett et al., 2003, Fahey et al., 2001). It has been used for the treatment of inflammation, infectious diseases, cardiovascular, gastrointestinal, hematological and hepatorenal disorders (Ghazal et al.,2012, Sinha et al.,2012, Adegbite et al.,2016).

All these uses have not yet been scientifically verified, but Moringa oleifera is considered an effective treatment for anemia, loss of appetite and it increases lactation in women (Ogbunugafor et al.,2012). It also combats gastric discomfort, stomach ulcers, diarrhea, dysentery, colitis and can be used as a laxative, purgative and a diuretic - to fight colds, bronchial infections, fever and head pain - rheumatic discomfort, muscular cramp, bruises and bruises - skin infections, scabies, ringworm and insect bites (Misra et al.,2014). In certain cases of diabetes, Moringa oleifera can also be used to stabilize sugar levels and can stabilize arterial tension (Divya et al.,2012). Most of plants uses for medicinal purposes have been correlated to their possession of antioxidant activity (Djacbou et al.,2014).

Black walnut, Juglansnigra, is an abundant tree of the eastern deciduous forest region of North America (Jelodar et al.,2007). The African walnut has indigenous names such as Ukpa (Igbo), Asala (Yoruba) and Hawuusa (Hausa) in Nigeria (Aladeokin and Umukoro, 2011). The walnut kernels have high oil content and were a favorite food of Amerindians (Crews et al.,2005). They retain their flavor when cooked and have a food value four times as great as meat (Jaradat,2005). They are very difficult to crack and the husk stains the hands a dark brown so their wild harvest today is restricted to the very dedicated (Cosmulescu et al.,2009). These nuts are used mainly in the candy and ice cream industries, the tree is very productive and can be grown in a variety of soils and climates (Davis et al.,2007). Walnuts provide a valuable timber and also a brownish-black dye that was used 
by early settlers to dye hair (Bonamonte et al.,2001). Studies have shown that walnuts are effective in preventing gallstones (especially in women) and lower serum cholesterol in Japanese men and women (Iwamoto et al.,2000, SeedGuides, 2013). Melatonin which is a powerful antioxidant and also induces a good night's sleep, is present in walnuts in the bio-available form (Reiter et al.,2005, Rahimipanah et al.,2010). Walnuts are an excellent source of a proteins, fiber, B vitamins and minerals like iron, magnesium, phosphorus, copper and manganese (Sze-Tao and Sathe, 2000, Muradoglu et al.,2010). These nuts are helpful in easing constipation due to their laxative effects and prevent liver damage (Hiroshi et al.,2008). Research indicates that walnuts may reduce the risk of Alzheimer's disease by arresting the formation of the amyloid plaques that are found in the brains of patients who suffer from this debilitating disease (Willis et al., 2009).

This study investigates the effects of cadmium on the lateral geniculate body of developing male wistar rats and ameliorative potential of Moringa oleifera seed oil and walnut oil extracts.

\section{MATERIALS AND METHODS}

Moringa oleifera seeds were obtained from a local market in Jos, Plateau State, Nigeria and walnuts were procured from a local market in Ilorin, Kwara State, Nigeria. These seeds were then taken to $\mathrm{Mr}$ Jeromes a botanist in the Department of Biology, Bingham University Karu, Nasarawa State for proper identification, voucher deposited for reference purpose.

All experimental investigations were done in compliance with humane animal care as studied in the "Guide to the care and use of Laboratory Animals Resources". National Research Council, DHHS, Pub. No NIH 86-23 (1985).

The study was carried out on thirty-five (35) young male wistar rats of body weight 80 $120 \mathrm{~g}$. The rats were reared in the animal holdings of Bingham University Karu, Nasarawa State, Nigeria. The rats were allowed to gain maximum acclimatization before the actual commencement of the experiment. The rats were housed five in a standard laboratory cage, at a constant room temperature in a 12 hrs light: 12 hrs dark (lights on 8 a.m. -8 p.m.) cycle. They were fed with $100 \mathrm{~g}$ standard rat diet chow daily containing proteins, carbohydrate, fats, vitamins and minerals which was purchased from Vital Feeds and Grand Cereals Ltd (Jos, Nigeria) to avoid changes in dietary compositions and weight variability and $200 \mathrm{ml}$ of normal drinking tap water was provided ad libitum.

The thirty-five (35) young male wistar rats used in this study were randomly divided into seven (7) groups, A, B, C, D, E, F and G of five (5) animals each.

Fresh walnuts and Moringa oleifera seeds weighing $1500 \mathrm{~g}$ each were oven dried at $40^{\circ} \mathrm{C}$ for 7days and were blended separately with nuts and seeds blender. The molten Moringa oleifera seeds and walnuts were then independently poured into an oil extraction machine that separated the oil from the residue at high temperature and pressure. The oil obtained was then kept at about $6^{\circ} \mathrm{C}$ $10^{\circ} \mathrm{C}$ under reduced pressure in order to maintain the constant temperature of the oil.

Cadmium sulphate solution was prepared by dissolving the $2.5 \mathrm{mg}$ of cadmium sulphate salt $\left(\mathrm{CdSO}_{4} .8 \mathrm{H}_{2} \mathrm{O}\right)$ in $20 \mathrm{ml}$ of $0.9 \% \mathrm{w} / \mathrm{v}$ normal saline solution. Ascorbic acid (vitamin C) was prepared by dissolving $5 \mathrm{mg}$ of vitamin $\mathrm{C}$ in 10 $\mathrm{ml}$ of $0.9 \% \mathrm{w} / \mathrm{v}$ normal saline solution. Vitamin E (Alpha tocopherol) was prepared by dissolving $6 \mathrm{mg}$ of vitamin $\mathrm{E}$ in $20 \mathrm{ml}$ of olive oil.

The animals were treated as shown in the table below: 
Table 1: Number of animals per group and dosage of treatment rendered

\begin{tabular}{|c|c|c|}
\hline GROUPS & NUMBER OF ANIMALS & DOSAGE \\
\hline A & 5 & $3 \mathrm{ml}$ of $0.9 \%$ normal saline per $\mathrm{kg}$ bw \\
\hline B & 5 & $2.5 \mathrm{mg} / \mathrm{kg}$ bw cadmium Only \\
\hline $\mathrm{C}$ & 5 & $5 \mathrm{mg} / \mathrm{kg}$ bw vitamin C \& $6 \mathrm{mg} / \mathrm{kg}$ bw vitamin $\mathrm{E}$ \\
\hline $\mathrm{D}$ & 5 & $\begin{array}{l}5 \mathrm{mg} / \mathrm{kg} \text { bw vitamin C \& } 6 \mathrm{mg} / \mathrm{kg} \text { bw vitamin } \mathrm{E}+2.5 \\
\mathrm{mg} / \mathrm{kg} \text { bw cadmium }\end{array}$ \\
\hline $\mathrm{E}$ & 5 & $\begin{array}{l}2.5 \mathrm{mg} / \mathrm{kg} \text { bw cadmium + Moringa oleifera seed oil (4 } \\
\mathrm{mg} / \mathrm{kg} \mathrm{bw})\end{array}$ \\
\hline $\mathrm{F}$ & 5 & $2.5 \mathrm{mg} / \mathrm{kg}$ bw cadmium + walnut oil (4 mg/kg bw) \\
\hline G & 5 & $\begin{array}{l}2.5 \mathrm{mg} / \mathrm{kg} \text { bw cadmium + Moringa oleifera seed oil + } \\
\text { walnut oil ( } 2 \mathrm{mg} / \mathrm{kg} \text { bw each) }\end{array}$ \\
\hline
\end{tabular}

Animals were grouped into three control groups namely; the normal control $(A)$, the negative control (B) and the positive control (C). Normal control group A animals received $3 \mathrm{ml}$ of $0.9 \% \mathrm{w} / \mathrm{v}$ normal saline solution orally for a period of three (3) weeks. Negative control group $\mathrm{B}$ animals were induced intraperitoneally with $2.5 \mathrm{mg} / \mathrm{kg} 3 \mathrm{CdSO}_{4} .8 \mathrm{H}_{2} \mathrm{O}$ and after 72 hours of injection, the animals received $3 \mathrm{ml}$ of $0.9 \% \mathrm{w} / \mathrm{v}$ normal saline solution for 3 weeks. Positive control group C animals received $5 \mathrm{mg} / \mathrm{kg}$ body weight and 6 $\mathrm{mg} / \mathrm{kg}$ body weight of vitamins $\mathrm{C}$ and $\mathrm{E}$ orally respectively for 3 weeks.

Group D animals were the prophylactic group received $6 \mathrm{mg} / \mathrm{kg}$ body weight of vitamin $E$ and $5 \mathrm{mg} / \mathrm{kg}$ body weight of vitamin C for 3weeks followed by the intraperitoneal injection of $2.5 \mathrm{mg} / \mathrm{kg} 3 \mathrm{CdSO}_{4} .8 \mathrm{H}_{2} \mathrm{O}$ for $72 \mathrm{hrs}$.

Group E, F and $G$ animals served as the therapeutic treatment group. The animals in each group were injected intraperitoneally with $2.5 \mathrm{mg} / \mathrm{kg} 3 \mathrm{CdSO} 4.8 \mathrm{H} 2 \mathrm{O}$, after $72 \mathrm{hrs}$ of injection, the animals in group $E$ and $F$ received $4 \mathrm{mg} / \mathrm{kg}$ body weight of Moringa oleifera seed oil and $4 \mathrm{mg} / \mathrm{kg}$ body weight of walnut oil respectively for 3 weeks. The animals in group $\mathrm{G}$ received Moringa oleifera seed oil and walnut oil at $2 \mathrm{mg} / \mathrm{kg}$ body weight for 3 weeks.
The animals were administered orally via oral cannular with the $2 \mathrm{mg} / \mathrm{kg}$ Moringa oleifera seed and walnut oils, $5 \mathrm{mg} / \mathrm{kg}$ vitamin C, 6 $\mathrm{mg} / \mathrm{kg}$ vitamin $\mathrm{E}$ and $3 \mathrm{ml}$ of $0.9 \% \mathrm{w} / \mathrm{v}$ normal saline solution according to their body weights treated as shown in the table above for three (3) weeks. The animals were held with a glove with the left hand such that the neck region is held by the fingers to still the neck while being fed with the cannular; treatment was done every morning before the animals were fed. Twenty-four (24) hours after the last administration; the animals were sacrificed by cervical dislocation. They were laid in a supine position on the dissecting board and pinned through the fore and hind paws. A midline incision through the skin and muscles of the abdominal wall were made from the xiphisternum to the pubic symphisis, extended laterally at the lower end to achieve adequate exposure of the thoracic and abdominal cavities. The skulls of the animals were fractured open using brain forceps and the whole brain was carefully removed and weighed. The lateral geniculate body was then excised and fixed in $10 \%$ formol calcium for $72 \mathrm{hrs}$. This was done for all the animals in each of the groups labelled Groups A to G. The tissues were homogenized in $0.25 \mathrm{M}$ sucrose at $4^{\circ} \mathrm{C}$ after which it was processed for histological analysis.

At the end of the last administration (3 weeks) of treatment, blood samples were collected in $5 \mathrm{ml}$ plain serum bottles via the 
heart and the intraocular method using capillary tubes for enzyme analysis. Activity of Glucose-6-Phosphate Dehydrogenase in homogenate was measured using the method of Lohr and Walker (1974). The procedure is as shown in the reactive table below: Glutathione peroxidase activity in homogenate was determined using the method of Paglia and Valentine (1967) using the reagent kit made by Randox lab, Ardmore, Diamond road, Crumlin co, UK BT294QY. Enzyme activity of SOD was assayed according to the method of Mistra and Fridovich (1972) using reagent kit produced by Randox lab Itd. After the brains of the Wistar rats were harvested, they were placed in specimen bottles containing $40 \%$ formol calcium to prevent autolysis and after 24 hours, the brains were dissected to remove the Lateral Geniculate Body. The process of tissue for histological staining was used. Data for the oxidative enzyme tests were expressed as Mean \pm Standard Error of Mean (S.E.M). The data was analysed in SPSS 17.0 software (SPSS Incorporation, Chicago, USA) to determine the analysis of variance. Except where otherwise stated, $P \leq 0.05$ was taken as the level of significance.

\section{RESULTS}

Groups F (Cadmium + walnut oil) and G (Cadmium + walnut oil + Moringa oleifera seed oil) animals were observed to show a statistically significant $(p<0.05)$ increased superoxide dismutase activity in the brain tissue when compared with that of the group A (Normal control)

Groups C (Vitamin C \& E), D (Vitamin C \& E + cadmium), E (Cadmium + Moringa oleifera seed oil), F (Cadmium + walnut oil) and G (Cadmium + walnut oil + Moringa oleifera seed oil) animals were observed to show significant $(p<0.05)$ decreased in superoxide dismutase activity in the serum when compared with that of the control group A.

Groups B (Cadmium only), C (Vitamin C \& E), D (Vitamin C \& E + cadmium), E (Cadmium + Moringa oleifera seed oil), $\mathrm{F}$ (Cadmium + walnut oil) and G (Cadmium + walnut oil + Moringa oleifera seed oil) animals were observed to show significant $(p<0.05)$ increased in glutathione peroxidase activity in the brain tissue when compared with that of the group $A$.

Groups B (Cadmium only), C (Vitamin C \& E), $\mathrm{D}$ (Vitamin C \& E + cadmium), E (Cadmium +
Moringa oleifera seed oil), F (Cadmium + walnut oil) and $\mathrm{G}$ (Cadmium + walnut oil + Moringa oleifera seed oil) animals were observed to show significant $(p<0.05)$ decreased in glutathione peroxidase activity in the serum when compared with that of the group A (Normal control).

Groups F (Cadmium + walnut oil) and G (Cadmium + walnut oil + Moringa oleifera seed oil) animals were observed to show a significant increased $(p<0.05)$ metabolic activity in the brain tissue when compared with that of the Group A (Normal control).

Groups B (Cadmium only), C (Vitamin C \& E), D (Vitamin C \& E + cadmium), F (Cadmium + walnut Oil) and $\mathrm{G}$ (Cadmium + walnut oil + Moringa oleifera seed oil) animals were observed to show a significant $(p<0.05)$ decreased metabolic activity in the brain tissue when compared with that of the Group A (Normal Control).

This histology stain is a Nissl stain that stains both neurons and glia and bonds well with acidic parts of cells such as ribosomes, nuclei and nucleoli. It stains cell bodies a blue/violet. 
TABLE 2: Oxidative stress enzyme activity in the brain tissue and Serum and histochemical assay of carbohydrate metabolism in the brain tissue

\begin{tabular}{|c|c|c|c|c|c|c|}
\hline \multirow[t]{2}{*}{ Groups } & \multicolumn{6}{|c|}{ Parameters } \\
\hline & SOD1(U/ml) & $\begin{array}{ll}\text { SOD } & 2 \\
(\mathrm{U} / \mathrm{ml}) & \end{array}$ & $\begin{array}{ll}\text { GPX } & 1 \\
(U / L) & \end{array}$ & $\begin{array}{ll}\text { GPX } & 2 \\
(U / L) & \end{array}$ & $\begin{array}{l}\text { LDH } \\
(U / L)\end{array}$ & G6PD (U/L) \\
\hline $\mathbf{A}$ & $604 \pm 7$ & $281 \pm 6$ & $3458 \pm 35$ & $4355 \pm 30$ & $573 \pm 7$ & $3668 \pm 33$ \\
\hline B & $601 \pm 9$ & $279 \pm 9$ & $3872 \pm 40 *$ & $3689 \pm 47 *$ & $587 \pm 11$ & $4129 \pm 34 *$ \\
\hline C & $758 \pm 7$ & $252 \pm 6 *$ & $3783 \pm 48 *$ & $3460 \pm 65^{*}$ & $627 \pm 7$ & $4096 \pm 39 *$ \\
\hline D & $743 \pm 6$ & $244 \pm 5 *$ & $3659 \pm 11^{*}$ & $4578 \pm 12 *$ & $609 \pm 4$ & $3322 \pm 28 *$ \\
\hline $\mathbf{E}$ & $609 \pm 4$ & $244 \pm 5^{*}$ & $3101 \pm 36 *$ & $4669 \pm 66 *$ & $602 \pm 6$ & $3544 \pm 48$ \\
\hline $\mathbf{F}$ & $1419 \pm 182 *$ & $248 \pm 5 *$ & $9640 \pm 77 *$ & $4230 \pm 70$ & $4877 \pm 47 *$ & $2761 \pm 60 *$ \\
\hline G & $991 \pm 16 *$ & $112 \pm 6 *$ & $6157 \pm 57 *$ & $2220 \pm 47^{*}$ & $3091 \pm 35 *$ & $2368 \pm 47 *$ \\
\hline
\end{tabular}

Values are expressed as mean \pm SEM for $n=5 ; * p<0.05$, significantly dissimilar from control SOD 1 - Superoxide Dismutase in the Brain Tissue, SOD 2 - Superoxide Dismutase in the Serum, GPx1 Glutathione Peroxidase in the Brain Tissue, GPx2 - Glutathione Peroxidase in the Serum, LDH Lactase Dehydrogenase, G6PD - Glucose-6-Phosphate Dehydrogenase

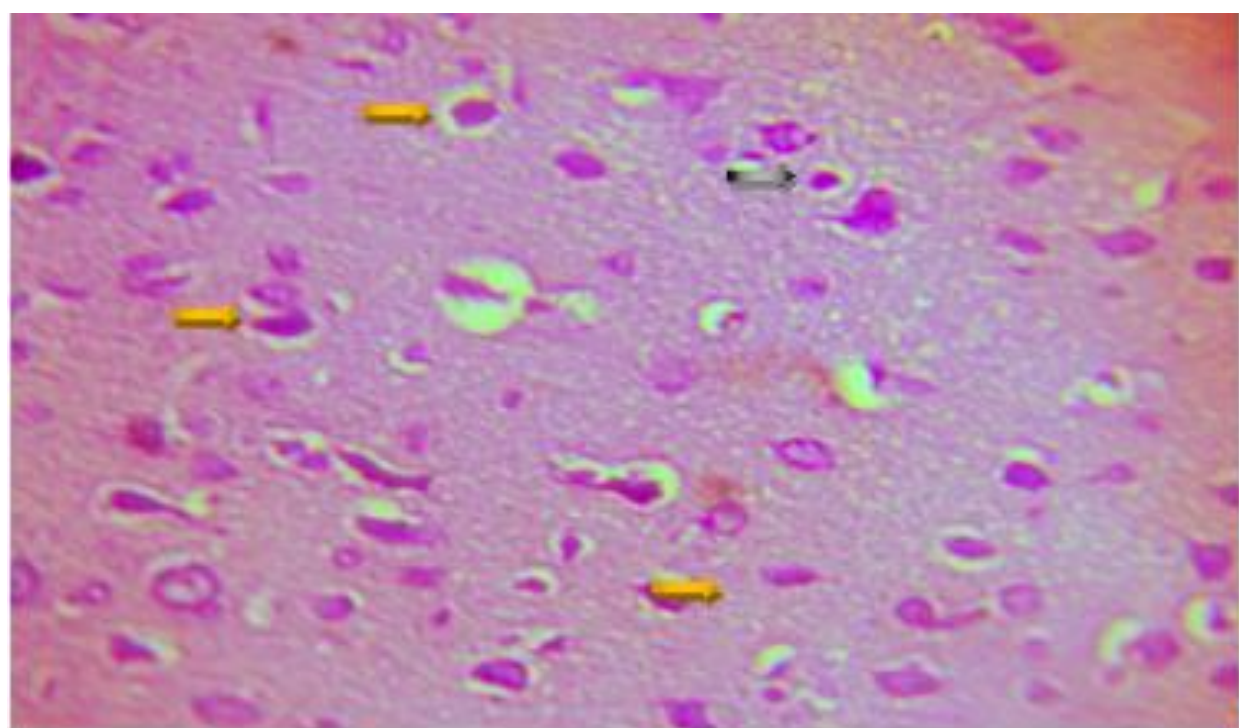

\section{Pyramidal Cells} Stellate Cells

Figure 1: Group A - Normal control (Administered $3 \mathrm{ml}$ of $0.9 \%$ normal saline per $\mathrm{kg}$ bw): Micrograph of longitudinal section of the lateral geniculate body of a rat. Neuronal cell shows normal architecture with layers visibly intact and dark coloured pyramidal cells indicate presence of sufficient nissl substance. Cresyl Fast Violet 400X 


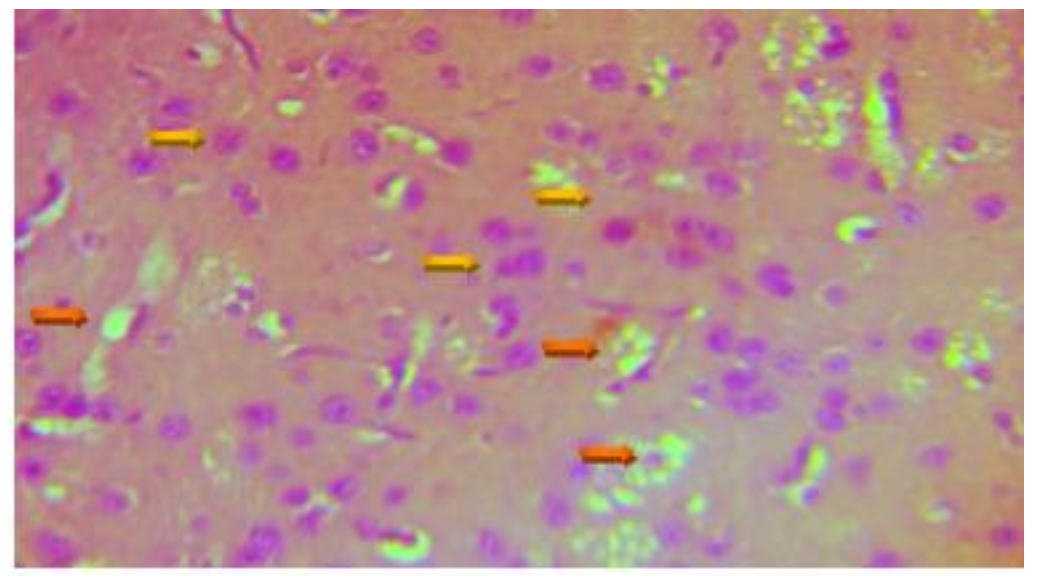

Figure 2: Group B - Negative control (Administered cadmium only): Micrograph of longitudinal section of the lateral geniculate body of a rat. Neuronal cells show signs of axonal degeneration indicating occurrence of apoptosis and light colored pyramidal cells indicate reduced nissl substance. Cresyl Fast Violet 400X
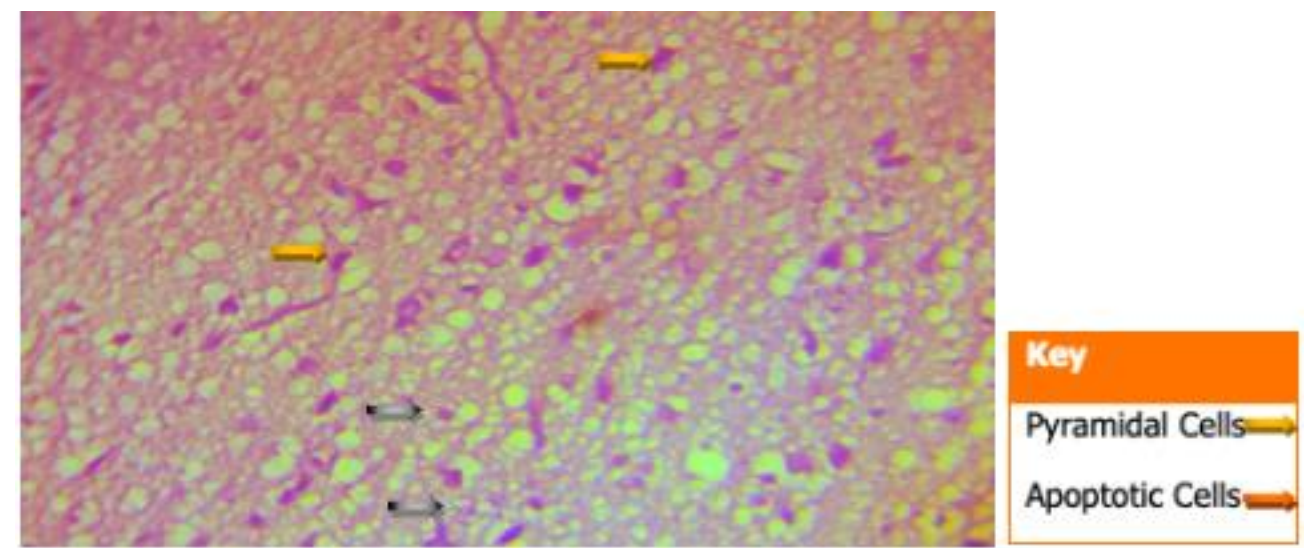

Figure 3: Group C - Positive control (Administered vitamin C \& E only): Micrograph of longitudinal section of the lateral geniculate body of a rat. Neuronal cell shows normal layered architecture; mildly dark coloured pyramidal cells indicate presence of sufficient nissl substance while numerous cells indicate cell regeneration. Cresyl Fast Violet 400X

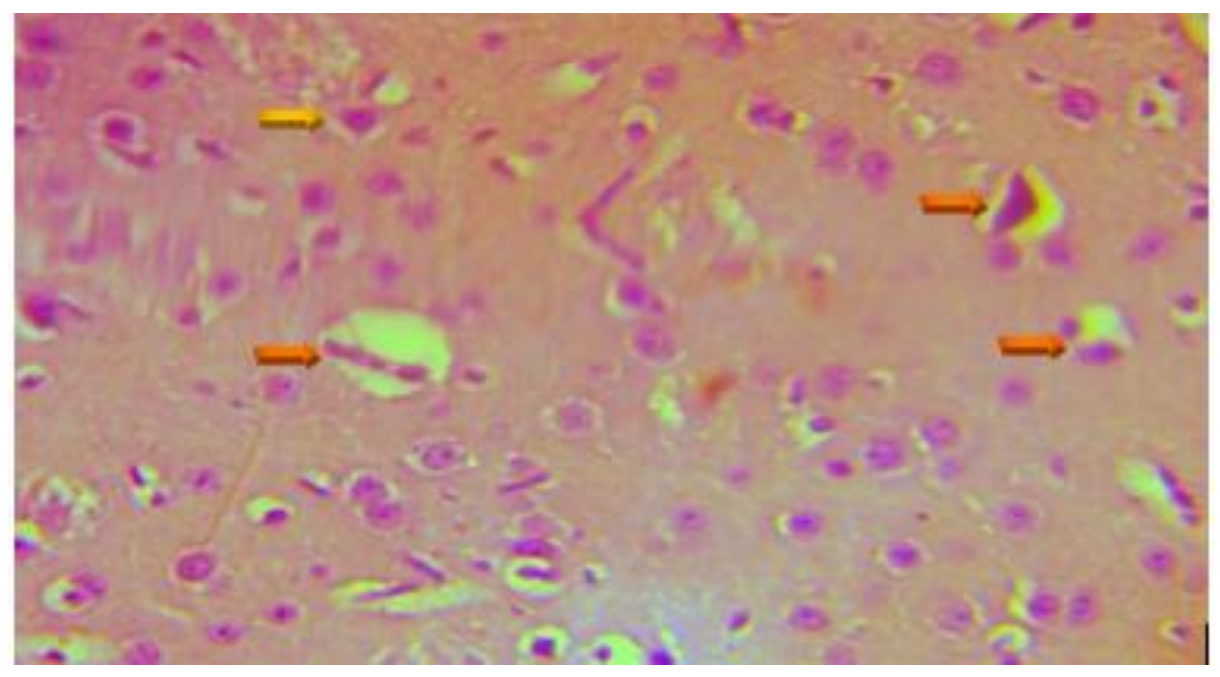

Figure 4: Group D - Positive induced (Administered vitamin C \& E + cadmium): Micrograph of longitudinal section of the lateral geniculate body of a rat. Layered cell architecture intact, but a few cells show signs of axonal degeneration indicating occurrence of apoptosis and medium light coloured pyramidal cells indicate reduced nissl substance. Cresyl Fast Violet 400X 


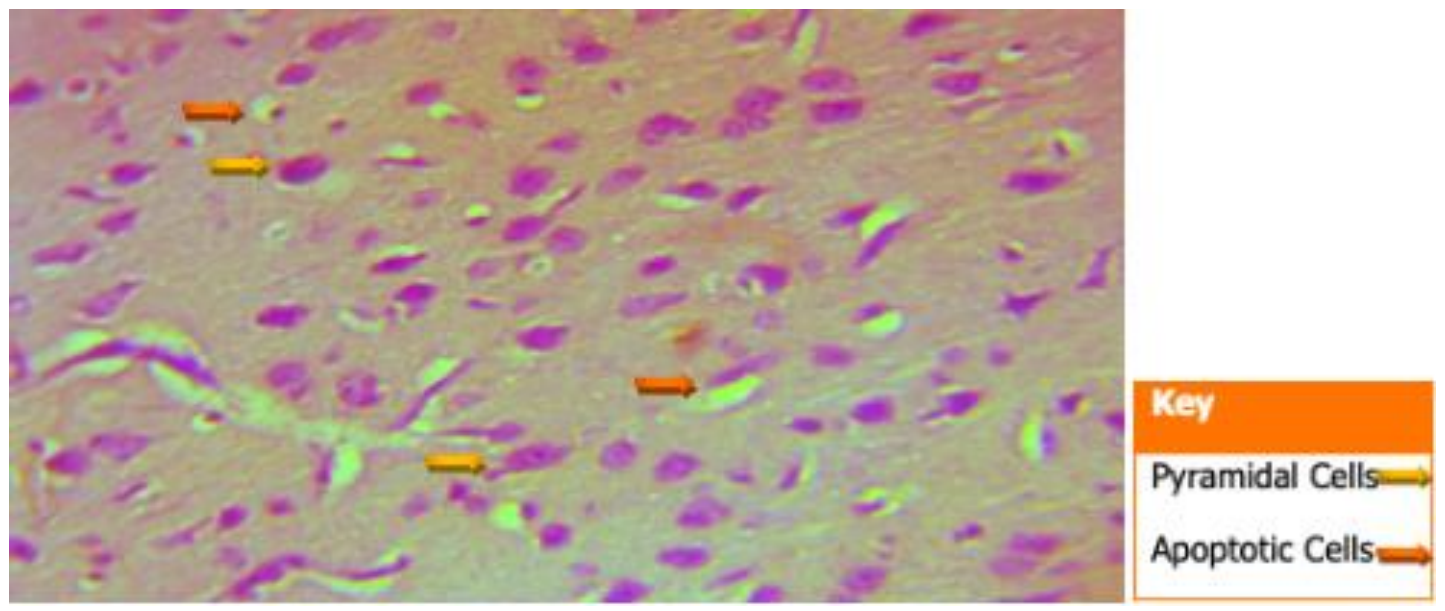

Figure 5: Group E - Administered cadmium + Moringa oleifera seed oil: Micrograph of longitudinal section of the lateral geniculate body of a rat. Layered cell architecture intact, but a few cells show signs of axonal degeneration indicating occurrence of apoptosis and medium light coloured pyramidal cells indicate reduced nissl substance, cell regeneration occurring. Cresyl Fast Violet 400X

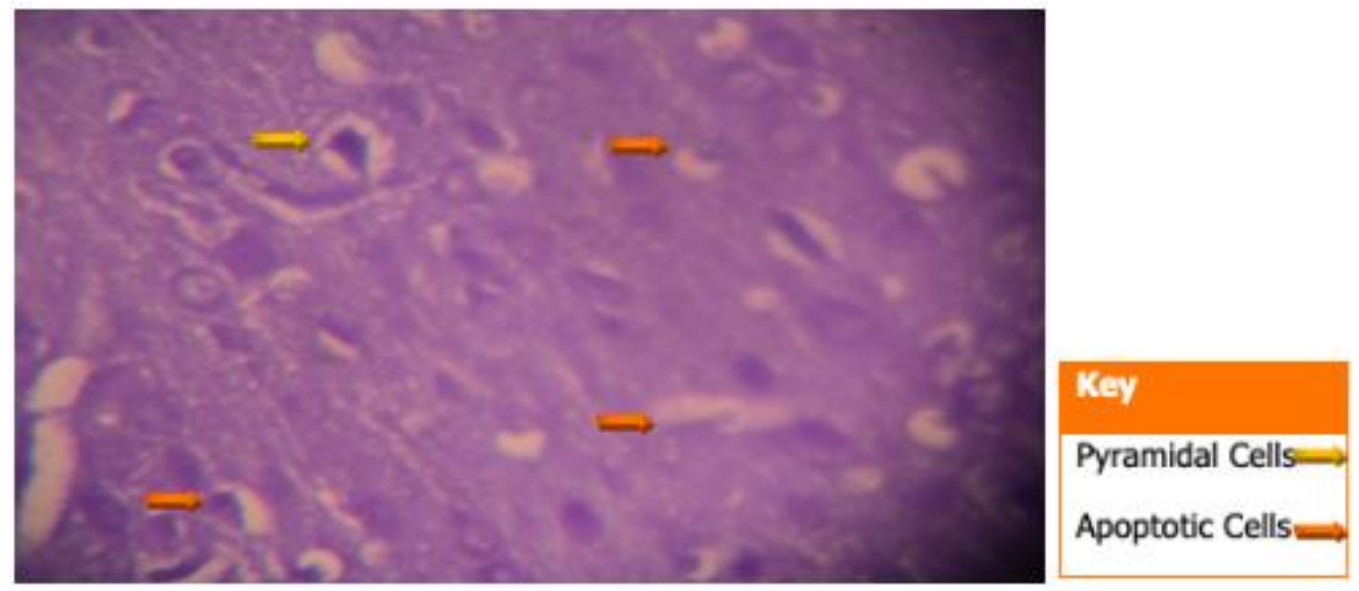

Figure 6: Group F - Administered cadmium + walnut oil: Micrograph of longitudinal section of the lateral geniculate body of a rat. Few shrunken cells show signs of axonal degeneration indicating occurrence of apoptosis and some light colored pyramidal cells indicate reduced nissl substance, cell regeneration also occurring. Cresyl Fast Violet 400X
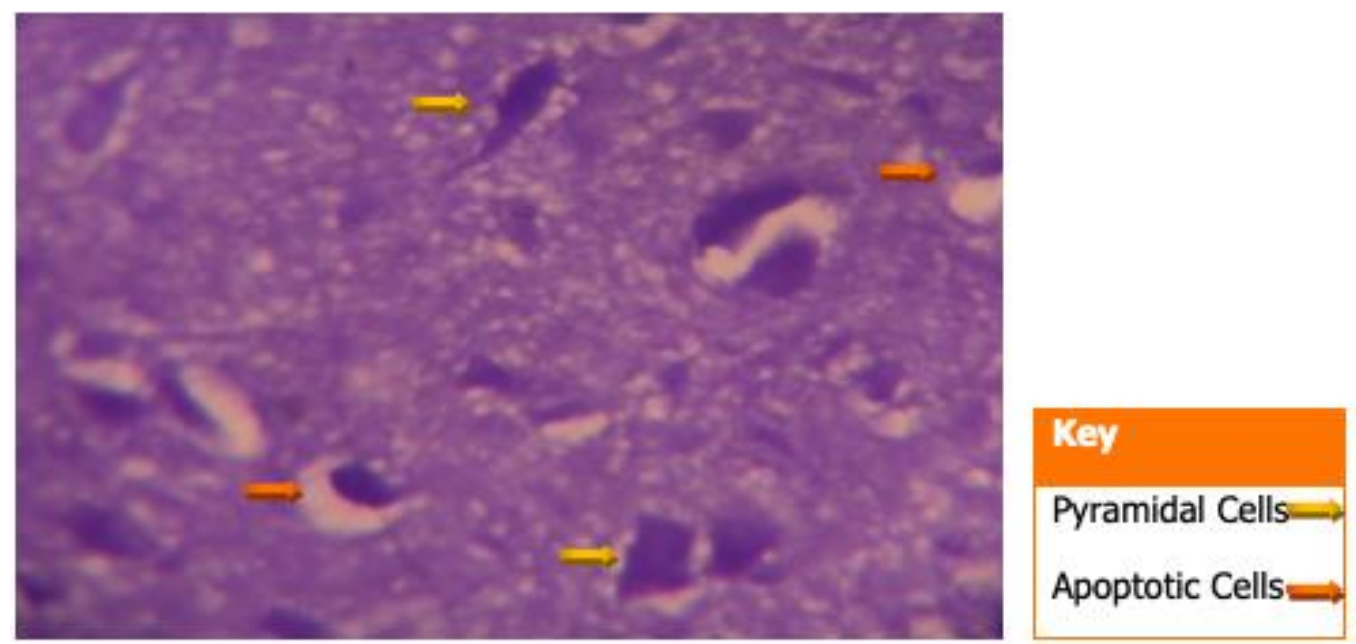

Figure 7: Group G - Cadmium + Moringa oleifera seed oil + walnut oil: Micrograph of longitudinal section of the lateral geniculate body of a rat. Few cells show signs of axonal degeneration indicating occurrence of apoptosis and dark coloured pyramidal cells indicate sufficient nissl substance, cell regeneration occurring. Cresyl Fast Violet 400X 


\section{DISCUSSION}

Cadmium (Cd) is known to produce a variety of health hazards in humans and experimental animals due to its ability to induce severe alterations in various organs and tissues including the nervous system, following either acute or chronic exposure (Manca et al., 1991). It promotes an early oxidative stress and afterward contributes to the development of serious pathological conditions (Bagchi et al., 2000).

Antioxidant enzymes such as SOD and GPx are some of the primary antioxidant enzymes, which help in degrading the toxic oxidative intermediates and are considered to be the first line of cellular defense against oxidative damage (Das et al.,2010). SOD is an antioxidant metallo enzyme that reduces superoxide radicals to water and molecular oxygen (Loschen et al.,1974). SOD catalyzes the dismutation of superoxide radicals by scavenging free superoxide anions (O2-). GPx uses GSH as a reducing substrate, and catalyzes the reduction of organic hydro peroxides (Ursini et al.,1995).

In this study administration of cadmium significantly decreased superoxide dismutase (SOD1) and Glutathione Peroxidase (GPx1) activity in the brain tissue Decreased activity of SOD reflects suppression of the scavenging ability of SOD, which may be a result of accumulation of superoxide anion radical in the brain tissue post cadmium treatment. The suppressing action of cadmium on SOD activity was also demonstrated by Ramanathan et al.,2002. Walnut Oil, Moringa oleifera seed oil co-treatment along with cadmium normalized SOD and GPx activity in the combined treatment group in the brain tissue when compared with that of the normal control group. This shows that, the combined action of the antioxidant contents of both oils increased SOD and GPx activity in the brain tissue in order to efficiently combat and mop up the free radicals and reactive oxygen species that had been released due to the oxidative damage induced by cadmium exposure. This thus confirms the suggestion made by Law et.al, (2001) that antioxidants have therapeutic importance in neurological disorders where oxidative stress is involved.

Also, superoxide dismutase (SOD2) and glutathione peroxidase (GPX2) activity in the serum in groups treated with vitamin $C \& E$, co-treated with vitamin $C \& E$, walnut oil and Moringa oleifera seed oil along with cadmium were observed to show significant decreased activity in the serum when compared with that of normal control. This implied that, oxidative damage induced by cadmium on the brain tissue resulted in the migration of the SOD and GPx enzymes from the blood to the brain in order to combat and mop up the free radicals and reactive oxygen species that had been released alongside the antioxidant contents of these drugs and herbs administered thereby, leading to an evidently decreased activity of SOD and GPx in the serum. This therefore concur with the report of Law et al.,2001 that in neurological disorders where oxidative stress is involved antioxidants have therapeutic importance. These results suggest that co-treatment with walnut oil and Moringa oleifera seed oil, helped maintain the balance between ROS production and antioxidant defense, as can be inferred from normalized antioxidant enzyme activity values in the combined treatment group. There are reports supporting the protective role of walnut oil and Moringa oleifera seed oil, against oxidative stress (Emerit et al.,2002).

Observation on the enzymes of carbohydrate metabolism such as lactate dehydrogenase (LDH) metabolism in the brain tissue of groups administered with cadmium and walnut oil, cadmium + walnut oil + Moringa oleifera seed oil animals were observed to show a significant increased metabolic activity in the brain tissue in comparison with the normal control. This shows that oxidative stress had occurred in the brain tissue due to the administration of the toxic cadmium and the antioxidant contents of both oils helped to increase the activity of the LDH enzyme in order to efficiently mop up and combat the free radicals and reactive oxygen species that had been released in the brain tissue due to 
the oxidative damage. This confirms the suggestion made by Stohs and Bagchi, (1995) that cadmium is a potent cell poison and its toxicity was mediated by the oxidative damage of essential cellular macromolecules and that of Peter et.al.,1995 that Free radical scavengers and antioxidants, such as Glutathione, vitamin $\mathrm{E}$, and vitamin $\mathrm{C}$ are capable of protecting against cadmium toxicity.

Also in our study Glucose-6-Phosphate Dehydrogenase (G6PD) metabolism in the brain tissue in groups treated with cadmium induced, vitamin $C$ \& $E$, vitamin $C$ \& $E$ + cadmium, cadmium + walnut oil and cadmium + walnut oil + Moringa oleifera seed oil groups animals were observed to show a significant decreased metabolic activity in the brain tissue suggest a disruption in carbohydrate metabolism pathway and depletion of the antioxidant defence system as evident in cadmium group rats (Stohs et al.,2000). This also revealed occurrence of oxidative stress in the brain tissue due to the administration of the toxic cadmium however antioxidant contents of both the drugs and oils were sufficient enough to efficiently mop up and combat the free radicals and reactive oxygen species that had been released in the brain tissue due to the oxidative damage thus requiring no more help from the glutathione antioxidant usually released by G6PD following oxidative damage and concomitantly resulting in the decreased level of the G6PD enzyme in the brain tissue. This there confirms the report of Stohs and Bagchi, (1995) that cadmium is a potent cell poison and its toxicity was mediated by the oxidative damage of essential cellular macromolecules and that of Peters et al., (1995) that free radical scavengers and antioxidants, such as glutathione, vitamin $\mathrm{E}$, and vitamin $\mathrm{C}$ are capable of protecting against cadmium toxicity.
Furthermore, in the present study, administration of cadmium was observed to have induced morphopathological changes in the lateral geniculate body of the brain involving the different types of neurons (Fig.2) when compared to the normal morphology of the lateral geniculate body of the rat brains in the normal control group $A$ (Fig. 1). The neurons were observed to have undergone either degenerative or apoptotic changes, the degenerative changes manifested by shrinkage, neurofibrillary tangles, senile plaques and deeply stained neurons in the studied regions. However, in Fig. 3-7, the neurons showed cellular regeneration after they had undergone either degenerative or apoptotic changes manifested by shrinkage, neurofibrillary tangles, senile plaques and deeply stained neurons in the studied regions. This shows that the administration of the vitamin $\mathrm{C}$ and $\mathrm{E}$ antioxidants and the antioxidant containing Moringa oleifera and walnut oil extracts actually helped to curb the deleterious effects of the toxic cadmium.

In conclusion, in the present investigation, the vitamin $\mathrm{C}$ and $\mathrm{E}$ antioxidant contents of Moringa oleifera seed oil and walnut oil helped to curb the morphopathological changes caused by the Cadmium induced damage to the lateral geniculate body of the rats' brain, maintained the activity of enzymes of Carbohydrate metabolism i.e. Lactate Dehydrogenase (LDH) and Glucose-6Phosphate Dehydrogenase, and the activity of the oxidative stress enzymes i.e. Superoxide Dismutase (SOD) activity and Glutathione peroxidase (GPx) concentration produced in the lateral geniculate body of the brain and serum nearly at control values. Also, the combined action of the antioxidant contents of both oils evidently attenuated the oxidative damage and morphological changes induced by cadmium in the lateral geniculate body of the brain of the rats.

Conflict of interest: Authors have declared that no competing interests exist.

\section{REFERENCES}

1. Bertin G1, Averbeck D .2006. Cadmium: cellular effects, modifications of biomolecules, modulation of DNA repair and genotoxic consequences (a review). Biochimie. 88(11):1549-1559.

2. Thévenod F .2009. Cadmium and cellular signaling cascades: to be or not to be? Toxicol Appl Pharmacol, 238(3):221-239 
3. Windholz M, Budavari S, Stroumtsos LY, Fertig MN. (editors) .1976. The Merck Index, 9th edn. Rahway, NJ: Merck.

4. Nawrot $T$, Plusquin M, Hogervorst J, Roels HA, Celis H, Thijs L, Vangronsveld J, Van Hecke E, Staessen JA. 2006. Environmental exposure to cadmium and risk of cancer: a prospective population-based study. Lancet Oncology ,7(2): 119-126.

5. Islamoglu S, Yilmaz L, Ozbelge HO. 2006. Development of a precipitation based separation scheme for selective removal and recovery of heavy metals from cadmium rich electroplating industry effluents. Sep. Sci. Technol, 41:3367-3385.

6. Pietrobelli JMTD, Modenes AN, Fagundes-Klen MR, Espinoza-Quinones FR. 2009. Cadmium, Copper and Zinc Biosorption Study by Non-Living Egeria densa Biomass, Water, Air, \& Soil Pollution, 202:385392

7. Wang HY, Gao HW .2009. Preparation of calcium oxalate-bromopyrogallol red inclusion sorbent and application to treatment of cationic dye and heavy metal waste waters. Environmental Science and Pollution Research ,16:339-347

8. Kurniawan TA, Chan GYS, Lo WH., Babel S .2006. Physico-chemical treatment techniques for wastewater laden with heavy metals. Chem. Eng. J, 118:83-98.

9. Liang YM, Jun M, Liu W .2007. Enhanced removal of lead(II) and cadmium(II) from water in alum coagulation by ferrate(VI) pre-treatment. Water Environment Research, 79: 2420- 2426

10. Government of Canada. 1994. Cadmium and its compounds. Priority Substances List Assessment Report." Government of Canada, Environment Canada and Health Canada ISBN 0-662-22046-3.

11. Deepti G, Preet S, Dua KK .2011. Prevention of Cadmium bioaccumulation by herbal adaptogen: Spirulina platensis. J. Chem. Pharm. Res, 3(5):603-608.

12. Jahangir T, Khan TH, Prasad L,Sultana S.2005. Alleviation of free radical mediated oxidative and genotoxic effects of cadmium by farnesol in Swiss albino mice. Redox Rep. 2005;10(6):303-310

13. Gonick HC .2008. Nephrotoxicity of Cadmium \& Lead. Indian J Med Res, 128: 335-352.

14. Houshmandfar A, Moraghebi F.2011. Effect of mixed cadmium, copper, nickel and zinc on seed germination and seedling growth of safflower. African Journal of Agricultural Research, 6(6); 14631468.

15. Sears ME, Kerr KJ, Riina I .2012. Arsenic, Cadmium, Lead, and Mercury in Sweat: A Systematic Review, Bray Journal of Environmental and Public Health, 184745:10

16. Khansakorn N, Wongwit W, Tharnpoophasiam P, Hengprasith B, Suwannathon L, Chanprasertyothin S, Sura T .2012. Genetic Variations of Glutathione S- Transferase Influence on Blood Cadmium Concentration. Journal of Toxicology, 356126:6

17. Aimola P, Carmignani M, Volpe AR, Di Benedetto A, Claudio L .2012. Cadmium Induces p53Dependent Apoptosis in Human Prostate Epithelial Cells. PLoS ONE, 7(3): e33647.

18. Ogbunugafor H, Igwo-Ezikpe U, Ozumba N, Aderekav S, Ugochukwu C, Onyekwelu O, Ekeehi A.2012. In vitro and in vivo Evaluation of Antioxidant Properties of MoringaoleiferaEthanolic Leaves Extract and Effect on Serum Lipid Indices in Rats. International Journal of Medical Sciences, 5(4): 397-403.

19. Jahn SAA.1988. Using Moringa seeds as coagulants in developing countries. Journal of American Water Works Association, 80; 43-50.

20. Fuglie $\sqcup$ (1999). The Miracle Tree: Moringa oleifera: Natural Nutrition for the Tropics." Church World Service, Dakar. 68 pp.; revised in 2001 and published as The Miracle Tree: The Multiple Attributes of Moringa, $172 \mathrm{pp}$.

http://www.echotech.org/bookstore/advanced search result.php?keywords=Miracle +Tree.

21. Abaliwano JK, Ghebremichael KA, Amy GL.2008. Application of the Purified Moringa Oleifera Coagulant for Surface Water Treatment. Watermill Working Paper Series, no. 5./.,mnbvc

22. Bennett RN, Mellon FA, Foidl N, Pratt JH, Dupont MS, Perkins L, Kroon PA .2003. Profiling glucosinolates and phenolics invegetative and reproductive tissues of the multipurpose trees Moringa oleifera L. (Horseradish tree) and Moringa stenopetala L. Journal of Agricultural and Food Chemistry, 51: 3546-3553.

23. Fahey JW, Zalcmann AT, Talalay P .2001. The chemical diversity and distribution of glucosinolates and isothiocyanates among plants. Phytochemistry ,56(1): 5-51.

24. Ghazal OK Owolabi JO, Williams FE, Lambe E .2012. Effects of Ethanolic Extract of Moringa Oleifera Leaves on Lead Acetate Induced Liver Damage in Adult Wistar Rats. Int. Jour Biotech Biomed Res, 2: 12: 4009 
25. Sinha M, Das DK, Datta S, Ghosh S, Dey S .2012. Amelioration of ionizing radiation induced lipid peroxidation in mouse liver by Moringa oleifera Lam. leaf extract. Indian Journal of Experimental Biology, 50(3):209-215.

26. Adegbite OA, Omolaso B, Seriki SA, Shatima C .2016. Effects of Moringa Oleifera Leaves on Hematological Indices in Humans. Ann Hematol Oncol, 3(8): 1107.

27. Misra A, Srivastava S, Srivastava M.2014. Evaluation of anti-diarrheal potential of Moringa oleifera (Lam.) leaves. Journal of Pharmacognosy and Phytochemistry. 2(5):43-46

28. Divya P, Sneha JA, Nulgumnalli M, Raghavendra .2012. Evaluation of the polyherbal extract for antioxidant, anticancer and antidiabetic activity. Ann. Phytomed ,1(1):39-45.

29. Djacbou DS, Pieme CA, Biapa PC, Penlap BV.2014. Comparison of in vitro antioxidant properties of extracts from three plants used for medical purpose in Cameroon: Acalypha racemosa, Garcinia lucida and Hymenocardia lyrata. Asian Pacific Journal of Tropical Biomedicine, 4(2): S625-S632

30. Jelodar G, Mohsen M, Shahram S .2007. Effect of walnut leaf, coriander and pomegranate on blood glucose and histopathology of pancreas of alloxan induced diabetic rats. Afr. J. Trad. CAM, 43: 299305

31. Aladeokin AC, Umukoro S .2011. Psycholpharmacological Properties of an Aqueous Extract of Tetracarpidium conophorum Hutch and Dalziel in Mice. J.Nat Med. 65; 411-416.

32. Crews C, Hough P, Godward J, Brereton P, Lees M, Guiet S .2005. Study of the main constituents of some authentic walnut oils. J. Agric. Food. Chem, 53:4853-4860.

33. Jaradat NA (2005). Medical plants utilized in Palestinian folk medicine for treatment of diabetes mellitus and cardiac diseases. J. Al-Aqsa Unv, 19:1-28

34. Cosmulescu S, Baciu A, Achim G, Botu M, Trandafir I .2009. Mineral Taha and Al-wadaan 5803 composition of fruits in different walnut (Juglans regia L.) Cultivars. Not. Bot. Hort. Agrobot. Cluj, 37:156-160.

35. Davis L, Stonehouse W, Loots DT, Mukuddem-Petersen J, Van Der Westhuizen F, Hanekom SJ, Jerling JC.2007. The effects of high walnut and cashew nut diets on the antioxidant status of subjects with metabolic syndrome. Eur. J. Nutr, 46: 155-164

36. Bonamonte D, Foti C, Angelini G .2001. Hyperpigmentation and contact dermatitis due to Juglans regia. Contact Dermatitis, 44: 101.

37. Seed Guides (2013). "Walnut Health Benefits, Walnut Nutrition, Side Effects and Facts." www. seedguides.info/walnuts/.

38. Iwamoto M, Sato M, Kono M, Hirooka Y, Saka K, Takeshita A, Imaizumi K .2000. Walnuts lower serum cholesterol in Japanese men and women. J. Nutr,130: 171-176.

39. Reiter RJ, Manchester LC, Tan DX .2005. Melatonin in walnuts: influence on levels of melatonin and total antioxidant capacity of blood. Nutrition, 21:920-924.

40. Rahimipanah M, Hamedi M, Mirzapour M. 2010. Antioxidant activity and phenolic contents of Persian walnut (Juglans regia L.) green husk extract. Afr. J. Food Sci. Technol, 1:105-111.

41. Sze-Tao KWC, Sathe SK .2000. Walnut (Juglans regia L): proximate composition, protein solubility, protein amino acid composition and protein in vitro digestibility. J. Sci. Food Agric, 80:1393-1401.

42. Muradoglu FH, Oguz I, Yildiz K, Yilmaz H .2010. Some chemical composition of walnut (Juglans regia L.) selections from Eastern Turkey. Afr. J. Agric. Res, 5: 2379-2385

43. Hiroshi S, Tanaka J, Kikuchi M, Fukuda T, Ito H, Hatano T, Yoshida T .2008. Walnut polyphenols prevent liver damage induced by carbon tetrachloride and d-galactosamine: hepatoprotective hydrolysable tannins in the kernel pellicles of walnut. J. Agric. Food Chem, 56: 4444-4449

44. National Institutes of Health. Guide for the care and use of laboratory animals: DHEW Publication (NIH), revised. Office of Science and Health Reports, DRR/NIH, Bethesda, USA, 1985.

45. Willis LM, Shukitt-Hale B , Cheng V, Joseph JA .2009. Dose-dependent effects of walnuts on motor and cognitive function in aged rats. $\mathrm{Br}$ J Nutr, 101:1140-1144.

46. Lohr GW, Walker HD .1974. Glucose 6 phosphate dehydrogenase in method of enzymatic analysis." $3^{\text {rd }}$ edition. Varlag Chemie- Wehnheim, pg636.

47. Paglia DE, Valentine WN .1967. Studies on the quantitative and qualitative characterisation of erythrocyte glutathione peroxidase. J. Lab. Clin. Med. 70: 158-167.

48. Mistral HP, Fridovich J .1972. The role of superoxide anion in the antioxidation of epinephrine and a simple assay for SOD. J. Biol. Chem. 247: 3170-3175.

49. Manca D, Ricard AC, Trottier B, Chevalier G .1991. Studies on lipid peroxidation in rat tissues following administration of low and moderate doses of cadmium chloride. Toxicology,67: 303-323. 
50. Bagchi D, Josh SS, Bagchi M .2000. Cadmium and chromium induced oxidative stress, DNA damage, and apoptotic cell death in cultured human chronic myelogenous Leukemic K562 cells, promylocytic leukemic HL-60 cells, and normal human peripheral blood mononuclear cells. J Biochem Mol Toxicol, 14: 33-41.

51. Das AK, Dewanjee S, Sahu R, Dua TK, Gangopadhyay M, et al., 2010. Protective effect of Corchorusolitorus leaves against arsenic-induced oxidative stress in rat brain. Food Chem Toxicol., 48: 326-335.

52. Ursini F, Maiorino M, Brigelius-Flohé R, Aumann KD, Roveri A, et al.,1995. Diversity of glutathione peroxidases. Methods Enzymol,252: 38-53.

53. Law A., Gauthier S, Quuirion R .2001. Neuroprotective and neurorescuing effects of isoform-secific nitric oxide synthase inhibitors, nitric oxide scavenger, and antioxidant against betaamyloid toxicity. $\mathrm{Br}$ J Pharmacol, 133: 1114-1124.

54. Emerit J, Edeas M, Bricaire F.2004. Neurodegenerative diseases and oxidative stress. Biomed Pharmacother ,58: 39-46.

55. Stohs SJ, Bagchi D, Hassoun E, Bagchi M .2000. Oxidative mechanism in the toxicity of chromium and cadmium ions. J Environ Pathol Toxicol Oncol, 19:201.

56. Stohs SJ, Bagchi D,1995. Oxidative mechanisms in the toxicity of metal ions. Free Radic Biol Med ,18: 321-336.

57. Peters JM, Duncan JR, Wiley LM, Keen CL .1995. Influence of antioxidants on cadmium toxicity of mouse preimplantation embryos in vitro. Toxicology, 99: 11-18. 